\title{
RELATION OF SERUM URIC ACID TO BODY BULK, HAEMOGLOBIN, AND ALCOHOL INTAKE IN TWO SOUTH PACIFIC POLYNESIAN POPULATIONS
}

\author{
BY \\ J. GRIMLEY EVANS AND I. A. M. PRIOR \\ The Medical Unit, Wellington Hospital, New Zealand \\ AND \\ H. P. B. HARVEY \\ Physician, Royal Prince Alfred Hospital, Sydney, Australia
}

Two lines of inquiry have recently led to an interest in the distribution of serum uric acid levels (SUA) in healthy populations:

(1) The problem of defining normal limits and elucidating the genetic determinations of unusually high values (Finn, Tweedie, Hall, Dinsdale, and Bourdillon, 1966; French, 1965).

(2) The hypothesis that SUA may be related to psychological traits manifesting as "drive" or "achievement oriented behaviour" and may even act as an "endogenous cortical stimulant" (Brooks and Mueller, 1966; Kasl, Brooks, and Cobb, 1966).

Both these inquiries depend on the accurate identification of factors of physical constitution and environment which contribute to variation in SUA levels.

We report in this paper on some correlates of SUA among persons aged 20 and over in two South Pacific Polynesian populations, which were studied as part of a programme of comprehensive health assessment in South Pacific Polynesian and European groups that our Unit has been conducting since 1962 . Particular interest lies in the serum uric acid levels in Polynesian peoples, as these have been found to be high by European standards in the South Pacific (Prior and Rose, 1966), although not, apparently, in the North Pacific in Hawaii (Healey, Caner, Bassett, and Decker, 1966). There is also at present a high prevalence of gout among South Pacific Polynesians, which in New Zealand Maori males reaches 10 per cent. (Prior and Rose, 1966). It is, therefore, surprising to find that 19thcentury medical writers commented on the absence of gout in Maoris (Thomson, 1854), and this raises the possibility that some recent environmental innovation may be responsible. The study of
Polynesian groups at different levels of material development which are undergoing environmental change will be crucial in investigating this possibility.

\section{Populations}

One group consisted of the adult population of the isolated coral atoll of Pukapuka in the Northern Cook Islands. These people live under a subsistence level economy and their diet is composed chiefly of coconut, taro (a coarse root-crop related to the sweet potato), and fish. The entire population aged 20 and over cooperated in the survey carried out in 1964 . The second group comprised a sample of adults who had lived under town conditions for at least 10 years in Avarua in the Southern Cook Islands. In contrast to the Pukapukan environment, these people enjoy a cash economy with ready access to a varied diet, including canned goods. 98 per cent. of the nominated sample co-operated in this survey, also carried out in 1964 . Further details of the surveys have been published (N.Z. M.R.C. Special Report, 1966).

\section{Methods}

Heights were measured without shoes; subjects were weighed in the lightest of clothing, for which an allowance of $2 \mathrm{lb}$. was made. A sample of venous blood was drawn from all participants.

Haemoglobin was estimated by a cyanmethaemoglobin method using an E.E.L. colorimeter with 624 filter. Uric acid was measured by a non-enzymatic colorimetric method which has been shown to correlate well with uricase determinations, but gives readings $0.50 \mathrm{mg}$./ $100 \mathrm{ml}$. higher (Buchanan, Isdale, and Rose, 1965): serum was separated from the blood soon after drawing, and stored at $-10^{\circ} \mathrm{C}$. for at least 3 weeks before SUA estimation to remove non-specific chromogen. The standard error of the method during the surveys was $0.25 \mathrm{mg} . / 100 \mathrm{ml}$. 


\section{Results}

Table I includes the age and sex distribution of the subjects included in the analysis. A total of 26 persons from the original participants was excluded; these comprised 24 pregnant women (13 in Rarotonga, 11 in Pukapuka) excluded on account of the lowering of SUA during the first 6 months of pregnancy (Boyle, Campbell, Duncan, Grieg, and Buchanan, 1966; Steenstrup, 1956), one Rarotongan woman suffering from typhoid fever, and one Pukapukan woman with incomplete data.

TABLE I

SAMPLE SIZE, SERUM URIC ACID (mg./100 ml.) MEANS, AND STANDARD DEVIATIONS, BY AGE, SEX, AND SAMPLE

\begin{tabular}{|c|c|c|c|c|c|c|c|}
\hline \multirow{3}{*}{ Sex } & \multirow{3}{*}{ Age (yrs) } & \multicolumn{3}{|c|}{ Pukapuka } & \multicolumn{3}{|c|}{ Rarotonga } \\
\hline & & \multirow{2}{*}{ No. } & \multicolumn{2}{|c|}{ Serum Uric Acid } & \multirow{2}{*}{ No. } & \multicolumn{2}{|c|}{ Serum Uric Acid } \\
\hline & & & Mean & S.D. & & Mean & S.D. \\
\hline Male & $\begin{array}{l}20-29 \\
30-39 \\
40-49 \\
50-59 \\
60-69 \\
70-\end{array}$ & $\begin{array}{l}43 \\
47 \\
33 \\
32 \\
20 \\
13\end{array}$ & $\begin{array}{l}6 \cdot 8 \\
7 \cdot 1 \\
7 \cdot 0 \\
6 \cdot 8 \\
7 \cdot 6 \\
7 \cdot 4\end{array}$ & $\begin{array}{l}0 \cdot 8 \\
1 \cdot 4 \\
1 \cdot 0 \\
1 \cdot 2 \\
1 \cdot 0 \\
1 \cdot 6\end{array}$ & $\begin{array}{l}83 \\
45 \\
40 \\
40 \\
18 \\
17\end{array}$ & $\begin{array}{l}6 \cdot 8 \\
6 \cdot 7 \\
7 \cdot 3 \\
7 \cdot 4 \\
7 \cdot 0 \\
6 \cdot 1\end{array}$ & $\begin{array}{l}1.3 \\
1.4 \\
1.2 \\
1.6 \\
1.8 \\
0.7\end{array}$ \\
\hline Female & $\begin{array}{l}20-29 \\
30-39 \\
40-49 \\
50-59 \\
60-69 \\
70-\end{array}$ & $\begin{array}{l}47 \\
43 \\
26 \\
31 \\
21 \\
10\end{array}$ & $\begin{array}{l}6 \cdot 1 \\
6 \cdot 1 \\
6 \cdot 1 \\
6 \cdot 3 \\
6 \cdot 7 \\
6 \cdot 7\end{array}$ & $\begin{array}{l}1 \cdot 0 \\
1 \cdot 1 \\
1 \cdot 0 \\
1 \cdot 1 \\
1 \cdot 4 \\
1 \cdot 1\end{array}$ & $\begin{array}{l}74 \\
31 \\
40 \\
33 \\
21 \\
13\end{array}$ & $\begin{array}{l}5 \cdot 7 \\
5 \cdot 9 \\
6 \cdot 1 \\
6 \cdot 4 \\
6 \cdot 4 \\
6 \cdot 2\end{array}$ & $\begin{array}{l}1 \cdot 0 \\
1 \cdot 2 \\
1 \cdot 2 \\
1 \cdot 0 \\
1 \cdot 2 \\
1 \cdot 4\end{array}$ \\
\hline
\end{tabular}

As previously reported, the Cook Islanders have higher SUA levels than Europeans (Prior and Rose, 1966). The values found are summarized in Table I. In both groups, despite the exclusion of pregnant women, mean values tend to be higher for women aged 50 and over than for younger women. No consistent age trend is seen in the males.

As will be discussed in the next section, SUA is related to body bulk in these populations and, in order to examine any age trend, it is necessary to remove the effect of obesity, which also varies with age. The measure used was ponderal index - the height in inches divided by the cube root of weight in pounds. This is simply a method of adjusting body weight for differences in height. It has been validated as a measure of obesity, but suffers from the minor disadvantage that it is inversely associated with body bulk, i.e. the index diminishes as obesity increases.

Using regression coefficients derived separately for each age/sex group, the observed values were adjusted to the mean ponderal index of the appropriate total sample. The result is shown in Fig. 1. The graph suggests that a rise in female values with age occurs only after the menopause. In Caucasian populations a slight fall in mean female values from
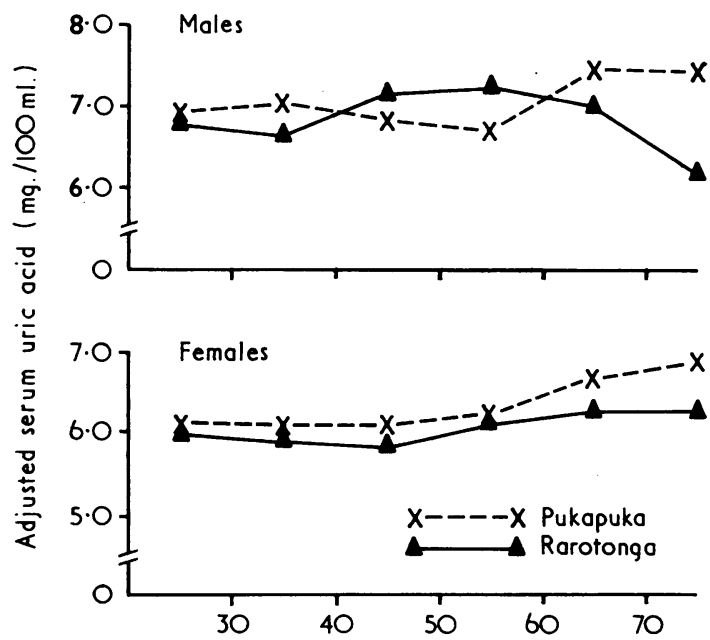

Age (yrs.)

Fig. 1.- Mean serum uric acid levels corrected for regression on ponderal index, by age, sex, and sample.

the third to the fourth decades has been observed (Mikkelsen, Dodge, and Valkenburg, 1965; Popert and Hewitt, 1962), which was not seen in either of the Polynesian groups, nor in a group of New Zealand Maoris studied previously (Prior, Rose, and Davidson, 1964). It is possible that this feature has been obscured by inaccuracy in the reported ages of the Polynesians. Analysis showed that there was no effect of parity on SUA values in either of the groups of women reported here.

\section{Body Bulk}

Fig. 2 (opposite) shows the frequency distributions of body weight and ponderal index (height in inches divided by the cube root of the weight in pounds) in the samples. Linear correlation coefficients between SUA and body weight were calculated in age- and sex-defined groups. In several of the groups the distributions of body weight were significantly skewed to the right, so corıelation coefficients were also calculated between SUA and a logarithmic transformation of weight which had a more consistently normal distribution. The transformation did not alter the significance pattern but gave slightly higher coefficients, which are presented in Table II (opposite).

Also shown in Table II are correlation coefficients between SUA and ponderal index (PI) which was normally distributed in most age groups. (The broadpeaked, or bimodal, distribution of PI in Rarotongan women seen in Fig. 3 (overleaf) is the result of merging the large group aged 20 to 29 years 


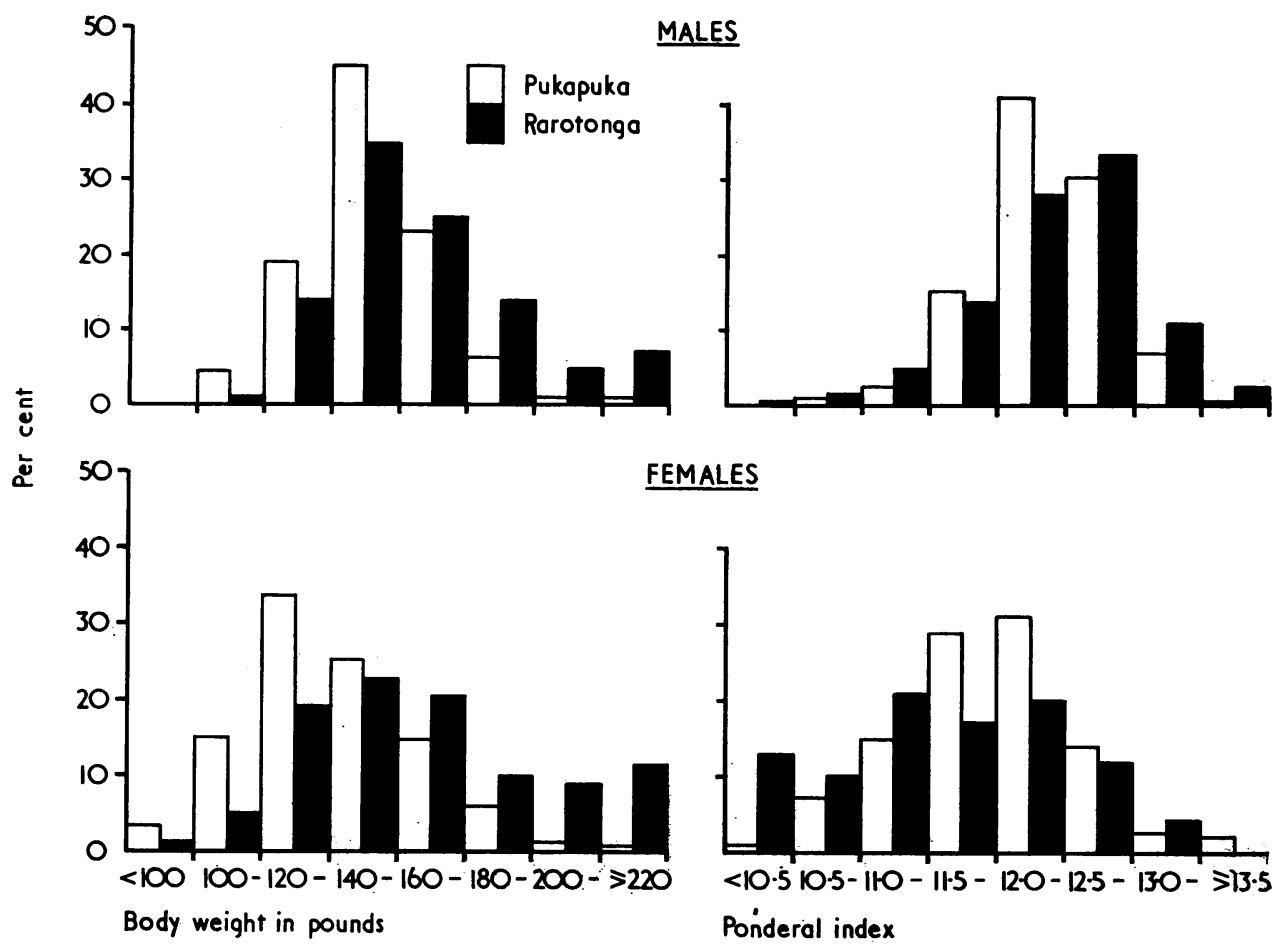

Fig. 2.-Per cent. distributions of body weight (lb.) and ponderal index, by sex and sample.

TABLE II

CORRELATION COEFFICIENTS BETWEEN SERUM URIC ACID AND LOG WEIGHT OR PONDERAL INDEX, BY AGE AND SEX

\begin{tabular}{|c|c|c|c|c|c|c|c|c|c|}
\hline \multicolumn{2}{|c|}{ Sex } & \multicolumn{4}{|c|}{ Male } & \multicolumn{4}{|c|}{ Female } \\
\hline \multirow{2}{*}{\multicolumn{2}{|c|}{ Population }} & \multicolumn{2}{|c|}{ Pukapuka } & \multicolumn{2}{|c|}{ Rarotonga } & \multicolumn{2}{|c|}{ Pukapuka } & \multicolumn{2}{|c|}{ Rarotonga } \\
\hline & & $\log W t$ & P.I. & $\log W t$ & P.I. & Log Wt. & P.I. & $\log W_{t}$ & P.I. \\
\hline $\begin{array}{l}\text { Age } \\
\text { (yrs) }\end{array}$ & $\begin{array}{l}20-29 \\
30-39 \\
40-49 \\
50-59 \\
60-69 \\
70-\end{array}$ & $\begin{array}{l}\cdot 08 \\
.15 \\
.09 \\
\cdot 24 \\
.37 \\
\cdot 13\end{array}$ & $\begin{array}{c}-\cdot 10 \\
-\cdot 32 * \\
.00 \\
-\cdot 33 \\
-\cdot 42 \\
-.03\end{array}$ & $\begin{array}{c}.08 \\
.43 \dagger \\
-.03 \\
.20 \\
.55^{*} \\
.28\end{array}$ & $\begin{array}{l}-.09 \\
-.47 \dagger \\
-.06 \\
-.11 \\
-.38 \\
-.50\end{array}$ & $\begin{aligned}-.04 \\
.19 \\
.51 * \\
-.13 \\
.16 \\
.65\end{aligned}$ & $\begin{array}{r}-\cdot 32 \\
-.21 \\
-\cdot 50 \\
.02 \\
-.29 \\
-.53\end{array}$ & $\begin{array}{r}.25 * \\
-.04 \\
.52 \dagger \\
.51 \dagger \\
.41 \\
-.07\end{array}$ & $\begin{array}{l}-.27^{*} \\
.02 \\
-.41 * \\
-.64 \dagger \\
-.40 \\
-.11\end{array}$ \\
\hline \multicolumn{2}{|c|}{ Pooled } & $\cdot 18^{*}$ & $-\cdot 21 \dagger$ & $\cdot 20 t$ & $-\cdot 19 t$ & $\cdot 14$ & $-.25 t$ & $.31 t$ & $-\cdot 35 t$ \\
\hline
\end{tabular}

(modal PI class $12 \cdot 0$ to $12 \cdot 4$ ), with the older, fatter subjects (modal PI class $11 \cdot 0$ to $11 \cdot 4$ )). The three series of correlation coefficients in population/sex groups were also pooled. In both populations and both sexes, PI showed a highly significant correlation with SUA $(P<\cdot 01)$. Overall, PI accounted for slightly more of the SUA variance than did body weight, and is used to adjust SUA values for body bulk in other analyses in this paper. Other combinations of height and weight, including DuBois' formula for body surface area, were tested for correlation with SUA in sub-samples, but were no better than the ponderal index.

\section{Haemoglobin}

The Pukapukans of both sexes have low values of haemoglobin compared with Rarotongans who, in turn, have slightly lower mean values than New Zealand Europeans (Prior, Morrison, Rose, and Davidson, 1965), particularly in females. Distri- 


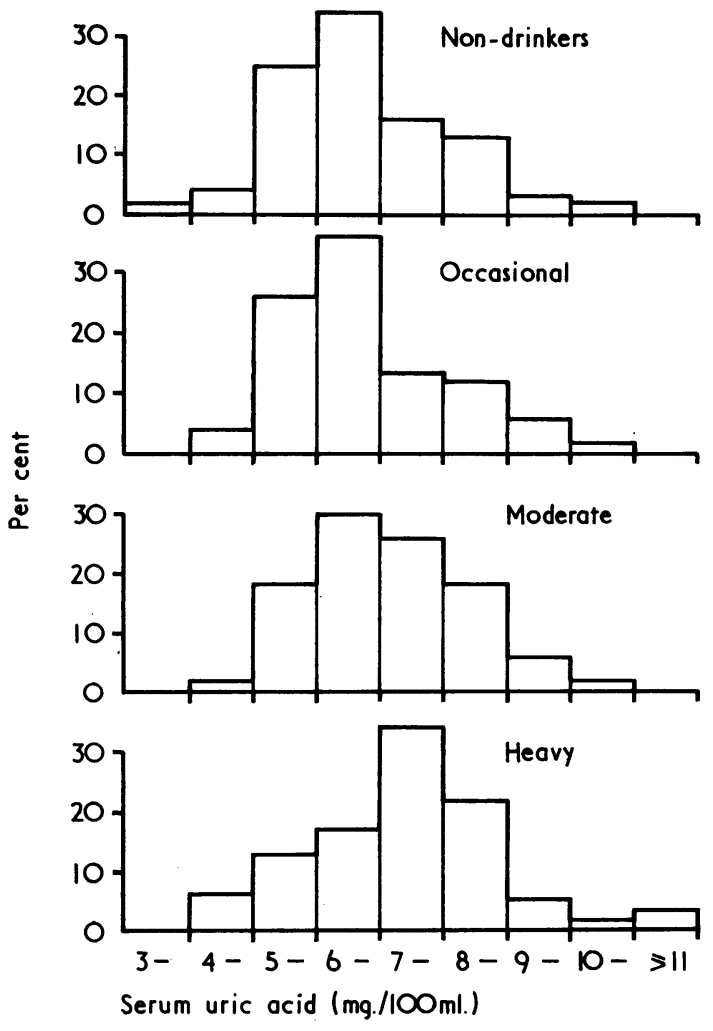

Fig. 3.-Rarotonga males. Per cent. distribution of serum uric acid values by habitual alcohol intake.

butions of haemoglobin values in the two populations have been published (M.R.C. Special Report, 1966). To search for a relation between SUA and haemoglobin it was again necessary to remove any interfering effect of obesity. This was done by means of first-order partial-correlation coefficients. These are a measure of the association between two variables when a third related variable is held constant. With ponderal index held constant, a significant correlation between SUA and haemoglobin is seen only among Pukapukan men aged 20 to 29 (Table III). There is no evidence from the results that SUA is correlated with haemoglobin in these populations, since the one significant coefficient in Table III might have arisen by chance alone. The use of packed cell volume instead of haemoglobin produced similar results.

\section{Alcohol Intake}

Although short-term increases in SUA following alcohol intake or infusion are reported (Lieber, 1965),
TABle III

FIRST ORDER CORRELATION COEFFICIENTS BETWEEN SERUM URIC ACID AND HAEMOGLOBIN, PONDERAL INDEX BEING HELD CONSTANT

\begin{tabular}{|c|c|c|c|c|c|}
\hline \multirow{2}{*}{\multicolumn{2}{|c|}{$\frac{\text { Sex }}{\text { Population }}$}} & \multicolumn{2}{|c|}{ Male } & \multicolumn{2}{|c|}{ Female } \\
\hline & & \multirow{2}{*}{$\begin{array}{c}\text { Pukapuka } \\
.54^{*} \\
-.03 \\
-.20 \\
-.33 \\
.30 \\
-.26\end{array}$} & \multirow{2}{*}{$\begin{array}{c}\text { Rarotonga } \\
-\cdot 19 \\
-.04 \\
-\cdot 30 \\
\cdot 15 \\
\cdot 23 \\
-\cdot 17\end{array}$} & \multirow{2}{*}{$\begin{array}{c}\text { Pukapuka } \\
-19 \\
-.08 \\
.21 \\
-.20 \\
-.33 \\
.17\end{array}$} & \multirow{2}{*}{$\begin{array}{c}\text { Rarotonga } \\
-.17 \\
.02 \\
-.08 \\
.10 \\
.42 \\
.11\end{array}$} \\
\hline $\begin{array}{l}\text { Age } \\
\text { (yrs) }\end{array}$ & $\begin{array}{l}20-29 \\
30-39 \\
40-49 \\
50-59 \\
60-69 \\
70-6\end{array}$ & & & & \\
\hline & oled & $t$ & $-\cdot 10$ & -.00 & -.01 \\
\hline
\end{tabular}

the relevance of habitual alcohol intake to epidemiological and clinical studies of SUA levels has not been extensively investigated. The use of alcohol is uncommon on Pukapuka, so this population is not considered further. In Rarotonga, habitual alcohol intake among the men was graded by one interviewing physician (I.A.M.P.) into occasional, moderate, and heavy. Alcohol drinking in this population occurs predominantly at weekends, and consists mostly of beer purchased at a store and drunk at home. Regular weekend drinkers were classified into the moderate or heavy groups. A subject who consumed twelve or more bottles of beer in a weekend, or reported regular intoxication, was classed as a heavy drinker. Some of the persons so classified would also drink during the week, and might also consume home-made alcoholic brews. Men who denied alcohol intake for at least 12 months were classed as non-drinkers. Table IV and Fig. 3 show that for Rarotongan males there is a tendency for mean SUA to increase with reported alcohol intake. Initial analysis showed that the different age groups were similar in their trends with alcohol intake, so all ages have been combined. The differences in ponderal index between the drinking groups were very small and the effect of adjusting the observed SUA values for their regression on ponderal index was negligible (Table IV, opposite).

The increase in mean SUA with increasing reported alcohol intake is consistent, with the main difference lying between moderate and heavy drinkers.

Six of the Rarotongan men were diagnosed as suffering from gout. Three of these were heavy drinkers, two were classified as occasional drinkers, and one denied taking alcohol.

\section{Discussion}

The higher SUA of South Pacific Polynesians in the Cook Islands and New Zealand compared with 
TABLE IV

MEAN PONDERAL INDEX, SERUM URIC ACID, AND ADJUSTED MEAN SERUM URIC ACID, BY HABITUAL ALCOHOL INTAKE FOR RAROTONGAN MALES

\begin{tabular}{|c|c|c|c|c|c|}
\hline Alcohol Intake & Non-Drinkers & Occasional & Moderate & Heavy & Not Known \\
\hline No. of Men $\ldots$ & 73 & 50 & 51 & 65 & 4 \\
\hline $\begin{array}{l}\text { Mean Ponderal Index } \\
\text { Mean SUA } \\
\text { Standard Deviation } \\
\text { Adjusted Mean SUA } \\
\text { (Standard Error) }\end{array}$ & $\begin{array}{r}12 \cdot 32 \\
6 \cdot 63 \\
1 \cdot 27 \\
6 \cdot 61 \\
(0 \cdot 15)\end{array}$ & $\begin{array}{r}12 \cdot 37 \\
6 \cdot 72 \\
1 \cdot 39 \\
6 \cdot 73 \\
(0 \cdot 20)\end{array}$ & $\begin{array}{r}12 \cdot 32 \\
7 \cdot 10 \\
1 \cdot 24 \\
7 \cdot 08 \\
(0 \cdot 18)\end{array}$ & $\begin{array}{r}12 \cdot 44 \\
7 \cdot 33 \\
1 \cdot 53 \\
7 \cdot 37 \\
(0 \cdot 19)\end{array}$ & $\begin{array}{r}12 \cdot 18 \\
8 \cdot 18 \\
1 \cdot 65 \\
8 \cdot 10 \\
(0 \cdot 96)\end{array}$ \\
\hline
\end{tabular}

Europeans has been commented on before (Prior and Rose, 1966). This is in contrast with the findings in a small group of Polynesians in Hawaii whose SUA values were similar to those of Caucasians (Healey and others, 1966), and, from the dispositions of the populations, both genetic and environmental factors could be relevant. Despite their higher values, the South Pacific Polynesian groups show variations with age and sex that are essentially similar to those in population groups of European origin (Mikkelsen and others, 1965; Popert and Hewitt, 1962), except for the absence of a fall in the fourth decade among women.

Although the relationship had been noted earlier in patients with cardiac and respiratory disease (Lewis and Gardner, 1960), Acheson and O'Brien (1966) were the first to report a correlation between SUA and haemoglobin levels in a general population. It was more prominent in men than in women. There is no evidence for a similar relationship in our samples, as the one significant correlation coefficient (for Pukapukan males aged 20-29) might have arisen by chance.

A positive relationship between SUA and body bulk has been reported in European and South Pacific Polynesian groups (Acheson and O'Brien, 1966; Dunn, Brooks, Mausner, Rodnan, and Cobb, 1963; Mikkelsen, 1965; Prior and others, 1964), and there is evidence of a similar relationship in other peoples (Burch, O'Brien, Need, and Kurland, 1966; O'Brien, Burch, and Bunim, 1966). The mechanism of the relationship is still obscure, and the measure of body bulk giving the best prediction of SUA varies from study to study. O'Brien and others (1966), studying Blackfeet and Pima Indians, found that body surface area gave the best correlation. Acheson and O'Brien (1966), in their Connecticut population, found a better relationship with weight in women and with ponderal index in men. In Tecumseh, the correlation of SUA was slightly better with observed weight in women and relative weight in men (Mikkelsen, 1965). In our data, ponderal index appears slightly better than weight in three of the four population/sex groups analysed. The difference is insignificant but raises the possibility that, in the Polynesians, SUA may be more closely related to obesity than to body size per se. Ponderal index correlates with relative obesity measured densitometrically, but is not an ideal measure since, in Caucasian populations at least, it probably overestimates the prevalence of obesity among short subjects, and underestimates it among the tall (Billewicz, Kemsley, and Thomson, 1962; Khosla and Lowe, 1967). We have no densitometric validation of ponderal index as a measure of obesity in our populations.

Our data indicate that SUA increases with reported alcohol intake among men at all ages. The method of rating intake was crude, and we have no independent check on its validity or reliability. The ratings were made independently of biochemical and physical findings, but might have been biased by some variable perceptible by the observer and correlated with SUA. With the exception of obesity, which was corrected for in the analysis, it is not clear what such a factor might be. We consider that it is more likely that the rating was subject to unsystematic error, so that the correlation of SUA with alcohol has been underestimated, perhaps severely.

This is not the first report of a relation between alcohol intake and SUA, but its relevance to the interpretation of epidemiological and clinical SUA determination has received little attention. A preliminary communication from the Tecumseh study reported a similar relationship between SUA and habitual alcohol intake (Dodge, 1965), and it has also been commented from the Framingham group that subjects with hyperuricaemia and with gout tended to consume more alcohol than the general population (Hall, 1965). Saker, Tofler, Burvill, and Reilly (1967) have recently reported a similar relationship in a group of Australian men selected as being either teetotallers or quotidian alcohol drinkers; occasional or intermittent drinkers were not 
included. Short-term increases in SUA following alcohol ingestion or infusion have been reported (Lieber, 1965), and our findings may simply show effect of drinking during the 24 hours or so before examination, perhaps potentiated by a reduced food intake during the period (Maclachlan and Rodnan, 1967). It is necessary, however, to exclude the possibility that alcohol intake may be a manifestation of constitutional factors which include, or result in, a raise SUA. Although it seems at first sight that alcohol intake is one more factor to be considered in accounting for the difference in SUA values between executives and craftsmen (Dunn and others, 1963), for example, it could be urged that alcohol intake, like executive status, is itself a direct, or a socially modulated, manifestation of high-drive behaviour which, in turn, is due in part to a high SUA. The hypothesis that SUA may act as an endogenous cortical stimulant, which is currently being proposed by Cobb and others (Brooks and Mueller, 1966; Dunn and others, 1963; Kasl and others, 1966), is obviously an important one. Delineation of the physical factors of constitution and environment associated with variation in SUA levels will be essential for testing such an hypothesis.

\section{Summary}

Serum uric acid determination from surveys on two South Pacific Polynesian Islands are reported. The Polynesians have higher mean levels than Europeans, but show essentially similar variations with age and sex, and positive correlations with measures of body bulk. There was no evidence of a relationship between SUA and haemoglobin. In the one group of men for which data were available, a positive relationship was found between SUA and reported habitual alcohol intake, which was independent of the association with body bulk. The relevance of these findings to epidemiological and clinical studies is discussed.

We wish to acknowledge the help received from other members of the survey team and the people of the Cook Islands. The work was supported by grants to the Wellington Hospital Medical Unit from the Medical Research Council of New Zealand, and from the World Health Organization. J.G.E. receives a grant from the Medical Research Distribution Committee of the Golden Kiwi Fund of New Zealand.

\section{REFERENCES}

Acheson, R. M., and O'Brien, W. M. (1966). Lancet, 2, 777 (Dependence of serum-uric-acid on haemoglobin and other factors in the general population).

Billewicz, W. Z., Kemsley, W. F. F., and Thomson, A. M. (1962). Brit. J. prev. soc. Med., 16, 183 (Indices of adiposity).

Boyle, J. A., Campbell, S., Duncan, A. M., Gre g, W. R., and Buchanan, W. W. (1966). J. clin. Path., 19, 501 (Serum uric acid levels in normal pregnancy with observations on the renal excretion of urate in pregnancy).

Brooks, G. W., and Mueller, E. (1966). J. Amer. med. Ass., 195, 415 (Serum urate concentrations among university professors).

Buchanan, M. J., Isdale, I. C., and Rose, B. S. (1965). Ann. rheum. Dis., 24, 285 (Serum uric acid estimation).

Burch, T. A., O'Brien, W. M., Need, R., and Kurland, L. T. (1966). Ibid., 25, 114 (Hyperuricaemia and gout in the Mariana Islands).

Dodge, H. J. (1965). Cited by F. H. Epstein in "Pathophysiological and Clinical Aspects of Lipid Metabolism", p. 149. Thieme, Stuttgart. (Epidemiological Investigation of Cardiovascular Disease and Related Disorders in a Complete Natural Community).

Dunn, J. P., Brooks, G. W., Mausner, J., Rodnan, G. P., and Cobb, S. (1963). J. Amer. med. Ass., 185, 431 (Social class gradient of serum uric acid levels in males).

Finn, R., Tweedie, M. C. K., Hall, S. M., Dinsdale, O. F., and Bourdillon, R. E. (1966). Lancet, 2, 185 (Frequency-distribution curve of uric acid in the general population).

French, J. G. (1965). "A Study of Familial Aggregation of Serum Uric Acid Levels in the Population of Tecumseh, Michigan 1959-1960". Doctoral Dissertation, University of Michigan.

Hall, A. P. (1965). Arthr. and Rheum., 8, 795 (in Proceedings of Conference on Gout and Purine Metabolism).

Healey, L. A., Caner, J. E. Z., Bassett, D. R., and Decker, J. L. (1966). J. Amer. med. Ass., 196, 364 (Serum uric acid and obesity in Hawaiians).

Kasl, S. V., Brooks, G. W., and Cobb, S. (1966). Ibid., 198, 713 (Serum urate concentrations in male high-school students).

Khosla, T., and Lowe, C. R. (1967). Brit. J. prev. soc. Med., 21, 122 (Indices of obesity derived from body weight and height). 
Lewis, J. G., and Gardner, J. E. (1960). J. clin. Path., 13, 502 (The relation of serum uric acid to haemoglobin level in patients with cardiac and respiratory disease).

Lieber, C. S. (1965). Arthr. and Rheum., 8, 786 (Hyperuricemia induced by alcohol).

MacLachlan, M. J., and Rodnan, G. P. (1967). Amer. J. Med., 42, 38 (Effects of food, fast and alcohol on serum uric acid and acute attacks of gout).

Mikkelsen, W. M. (1965). Arthr. and Rheum., 8, 853 (The possible association of hyperuricemia and/or gout with diabetes mellitus).

—- Dodge, H. J., and Valkenburg, H. (1965). Amer. J. Med., 39, 242 (The distribution of serum uric acid values in a population unselected as to gout or hyperuricemia, Tecumseh, Michigan, 1959-1960).

New Zealand Medical Research Council (1966). Special Report No. 26. M.R.C. of New Zealand and Department of Health, Wellington, New Zealand (The health of two groups of Cook Island Maoris).

O'Brien, W. M., Burch, T. A., Bunim, J. J. (1966). Ann. rheum. Dis., 25, 117 (Genetics of hyperuricaemia in Blackfeet and Pima Indians).

Popert, A. J., and Hewitt, J. V. (1962). Ibid., 21, 154 (Gout and hyperuricaemia in rural and urban populations).

Prior, I. A. M., Morrison, R. B. I., Rose, B. S., and Davidson, F. (1965). Unpublished observations.

— and Rose, B. S. (1966). N.Z. med. J., 65, 295 (Uric acid, gout and public health in the South Pacific).

,-- , and Davidson, F. (1964). Brit. med.J., 1, 1065 (Metabolic abnormalities in New Zealand Maoris).

Saker, B. M., Tofler, O. B., Burvill, M. J., and Reilly, K. A. (1967). Med. J. Aust., 1, 1213 (Alcohol consumption and gout).

Steenstrup, O. R. (1956). Scand. J. clin. Lab. Invest., 8, 263 (Hypo-uricemia during pregnancy).

Thomson, A. S. (1854). Brit. For. Med.-Chir. Rev., 14, 356 (On the pecularities in figure, the disfiguration and the customs of the New Zealanders: with remarks on their diseases and on their modes of treatment).

Le rapport entre l'acide urique dans le sérum et le volume corporel, l'hémoglobine et la consommation d'alcool dans deux populations polynésiennes du Pacifique du Sud

RÉSUMÉ

On rapporte les résultats des enquêtes concernant le taux d'acide urique sanguin des habitants de deux îles polynésiennes du Pacific du Sud. Le taux moyen des Polynésiens est plus élevé que celui des Européens, mais les variations selon l'age et le sexe sont essentiellement les mêmes et il existe la même corrélation positive en ce qui concerne la masse corporelle. On ne trouve aucun rapporte entre l'acide urique sanguin et l'hémoglobine. Dans un groupe d'hommes on obtint des données confirmant l'existence d'un rapport direct entre l'acide urique sanguin et la consommation habituelle avouée d'alcool, compte tenu de la masse corporelle. On discute la portée des résultats de cette enquête du point de vue épidémiologique et clinique.
La relación entre el ácido úrico en el suero y la masa del cuerpo, la hemoglobina y el consumo de alcohol en dos poblaciones polinesias del Pacífico del Sur

\section{Sumario}

Se relatan los resultados de las investigaciones de las cifras del ácido úrico en el suero de poblaciones en dos islas polinesias. Las cifras medias de los polinesios son más altas que las de los europeos, pero las variaciones según la edad y el sexo son esencialmente iguales, en razón directa con la masa del cuerpo. No hubo relación entre el ácido úrico en el suero y la hemoglobina. En el grupo de hombres en el cual se pudieron recoger los datos hubo una correlación positiva entre las cifras del ácido úrico del suero y el consumo habitual de alcohol, aún teniendo cuenta de la masa del cuerpo. Se discute la importancia epidemiológica y clínica de esta investigación. 